\title{
Fungsi public relations pada strategi merek Inspira TV dalam membangun brand perusahaan
}

\author{
Putri Aprilia $^{1}$, Hanny Hafiar ${ }^{2}$, Priyo Subekti ${ }^{3}$ \\ ${ }^{1,2,3}$ Universitas Padjadjaran, Bandung, Indonesia
}

\begin{abstract}
ABSTRAK
Persaingan industri pertelevisian semakin ketat dan memaksa para pelaku industri untuk dapat menciptakan merek perusahaan yang kuat untuk dapat memimpin pasar dan mencapai tujuan pemasaran. Maka dari itu diperlukan strategi merek untuk mewujudkan hal tersebut. Inspira TV sebagai televisi digital yang baru hadir di tengah masyarakat memerlukan strategi merek untuk memperkuat mereknya sebagai stasiun televisi digital yang inspiratif dan positif. Maka dari itu penelitian ini bertujuan untuk mengetahui fungsi public relations dalam kelima tahapan strategi merek yaitu tahap perencanaan, tahap memposisikan merek, tahap pengenalan merek perusahaan, tahap manajemen merek dan tahap menjaga merek. Penelitian ini menggunakan metode deskriptif dengan jenis data kualitatif. Hasil penelitian ini menunjukkan bahwa fungsi PR dalam tahap perencanaan Inspira TV diawali dengan menentukan target sasaran, melakukan riset pasar, penyampaian informasi dan membangun hubungan internal kemudian terbentuk strategi merek Inspira TV, fungsi PR pada tahap memposisikan merek dilakukan dengan menetapkan perbedaan program Inspira TV dan TV lain kemudian dibangun melalui market positioning dan brand image positioning, fungsi PR dalam tahap mengenalkan merek perusahaan adalah dengan mensosialisasikan perusahaan berserta produknya melalui strategi on air, off air, online dan pelaksanaan kegiatan sosial dengan tujuan untuk menciptakan citra positif dan dukungan publiknya, fungsi PR dalam tahap manajemen merek adalah dengan melakukan Customer Relation Management (CRM) dan media relations, fungsi PR dalam tahap menjaga merek adalah dengan mendaftarkan merek secara hukum, menjaga kualitas program dan menjaga citra perusahaan.
\end{abstract}

Kata-kata Kunci: Fungsi public relations; merek; strategi merek; televisi digital, Inspira TV

\section{Public relations function on brand strategy to build enterprise's $b$ rand by Inspira TV}

\begin{abstract}
The function of Public Relations (PR) is very important to be carried out by companies in the face of current competition similarly with television industry competition to lead the market. Inspira TV present in the community need brand strategy to strengthen enterprise's brand as an inspiring and positive digital television station. Therefore this study aims to determine the function of PR in the five stages of brand strategy, which are the planning, the brand positioning, the popularization enterprise's brand, brand management, and the brand protection. This study uses descriptive methods with qualitative data types. The result shows that, the PR function in the planning stage of Inspira TV starts from identifying the target market, doing market research, delivering information, and building internal relations then formed the Inspira TV brand strategy, the PR function in brand positioning stage was done by setting differences of Inspira TV programs and other TV stations, then built through market positioning and brand image positioning, the PR function in introducing the enterprise's brand was to socialize the company along with its products through on air, off air, online and social activitites strategies with the aim to create a positive image and getting the public support, the PR function in brand management stage was doing Costumer Relation Management (CRM) and media relation, the PR function in brand protection stage were registering the brand legally, maintaining the programs' quality, and maintaining the enterprise's image.
\end{abstract}

Keywords:Public relations function; brand; brand strategy; digital television, Inspira TV

Korespondensi: Putri Aprilia. Universitas Padjadjaran. Jalan Raya Bandung-Sumedang KM. 21 Jatinangor 45363 Email: putriaprilia2828@gmail.com 


\section{PENDAHULUAN}

Berbicara mengenai public relations (PR) atau Hubungan Masyarakat, artinya kita berbicara mengenai bagaimana sebuah perusahaan, organisasi atau institusi berkomunikasi dengan publiknya. PR sebagai fungsi manajemen yang memiliki tugas merancang strategi komunikasi bukan hanya untuk memberikan informasi perusahaan tetapi juga harus mampu membangun sebuah brand dari perusahaan tersebut. Secara umum Public relations melakukan komunikasi untuk menciptakan hubungan baik sehingga tumbuh citra positif terhadap merek perusahaan.

Merek (brand) adalah segala sesuatu yang terkait dengan perusahaan, produk, atau layanan. Merek bukan sekedar logo atau nama perusahaan, melainkan image atau persepsi seseorang tentang produk atau perusahaan. Dalam meningkatkan kekuatan mereknya, perusahaan akan berusaha memperkenalkan merek perusahaan karena keberadaan merek bukan hanya semata-mata menunjukkan nama dari sebuah produk, namun lebih dari itu, merek menunjukkan nilai tambah dari produk, yang membedakan produk tersebut dengan produk lain.

Merek yang baik perlu dikelola dan diatur dengan baik pula. Maka dari itu diperlukan strategi merek yaitu sebuah manajemen yang mengelola elemen-elemen yang bertujuan untuk membangun sebuah merek. Strategi merek perusahaan dapat memperluas pangsa pasar dengan cara menanamkan nilai tambah sebuah produk atau jasa. Dalam strategi merek inilah fungsi PR sangat penting dalam melakukan komunikasi yang sesuai untuk menanamkan nilai perusahaan sehingga dapat menciptakan citra positif terhadap merek tersebut. Strategi merek ini menjadi penting karena dapat menjadi bagian dari strategi bisnis.

Seperti menurut Xu Yuanzhong dalam penelitiannya mengungkapkan bahwa strategi merek adalah bagian penting dari strategi perusahaan dimana dalam penerapan strategi merek yang efisien sangat penting bagi perusahaan untuk berhasil dari persaingan pasar dan dengan penggunaan fungsi PR yang efektif dapat menerapkan strategi merek yang sukses (Yuanzhong, 2005).

Dalam penelitian lainnya mengungkapkan bahwa strategi merek yang muncul dalam paradigma praktik untuk bersaing dalam era yang dipimpin oleh konsumen, merek dapat menjadi wadah untuk melibatkan konsumennya melalui nilai-nilai perusahaan yang ditawarkan sehingga membangun persepsi positif di benak konsumen mengenai produk atau perusahaan tersebut (Abimbola, 2010).

Sama halnya seperti Inspira TV sebagai salah satu televisi digital di Indonesia. Inspira 
TV merupakan stasiun televisi digital swasta yang hadir sejak tanggal 15 Juni 2016 melalui kesepakatan masa uji coba siaran televisi digital. Fenomena televisi (TV) digital di Indonesia sendiri masih sangat baru dan belum banyak masyarakat Indonesia memahami TV digital sehingga penggunaan TV analog masih sangat mendominasi pasar. Hal ini membuat perusahaan yang bergerak di TV digital harus membangun mereknya agar dikenal dan menjadi populer di masyarakat.

Sehingga Inspira TV sebagai perusahaan yang baru muncul memiliki tujuan agar Inspira TV dapat populer ditengah masyarakat Indonesia dan dapat unggul dalam persaingan pasar di industri pertelevisian. Untuk mendukung tujuan tersebut fungsi PR dalam membangun brand perusahaan pun dikelola oleh Inspira TV melalui bagian brand management.

Inspira TV adalah stasiun televisi digital yang hadir untuk memenuhi kebutuhan informasi dan hiburan bagi anak muda Indonesia. Dengan semangat "Inspiratif dan Positif”, Inspira TV sendiri memiliki tujuan untuk memberikan tayangan yang dapat bermanfaat bagi masyarakat luas dan mendidik terutama bagi generasi penerus bangsa. Sejak awal ditentukan siaran TV digital, Inspira TV sudah menyiapkan diri untuk menyasar anak muda atau generasi millenial. Namun pada kenyataannya hingga saat ini, penonton televisi di TV terestrial itu sendiri adalah segmentasi yang berbeda dari yang ditentukan yakni berasal dari segmentasi yang usianya lebih dewasa.

Fenomena ini pun turut didukung oleh hasil riset dimana saat ini sudah terjadi perubahan dalam pola menonton TV terutama bagi generasi milenial yang sudah jarang duduk berjam-jam di hadapan layar TV untuk mengikuti sebuah acara (Abdullah \& Puspitasari, 2018)

Menyadari hal tersebut akhirnya Inspira TV menghadirkan aplikasi menonton yang dapat diaskes dengan mudah oleh generasi millenial yang dekat dengan dunia online melalui smartphonenya. Dengan begitu mereka dapat mengakses tayangan Inspira TV secara tidak terbatas, kapan pun dan dimana pun.

Namun menyaksikan siaran televisi oleh generasi millenial melalui $\mathrm{TV}$ streaming bukanlah aktivitas utama ketika mereka mengakes Internet di smartphonenya. Dari survei yang dirilis dalam Indonesia Millenial Report 2019, tercatat bahwa aktivitas nomor 1 yang dilakukan para millenial dengan akes Internet adalah kegiatan berkomunikasi dimana chatting atau messaging merupakan kegiatan yang terbanyak dilakukan, dapat dilihat pada gambar 1.

Melalui Indonesia Millenial Report 2019 yang dilakukan oleh IDN Research Institute dapat dilihat bahwa selain chatting, aktivitas yang sering dilakukan generasi millenial saat 


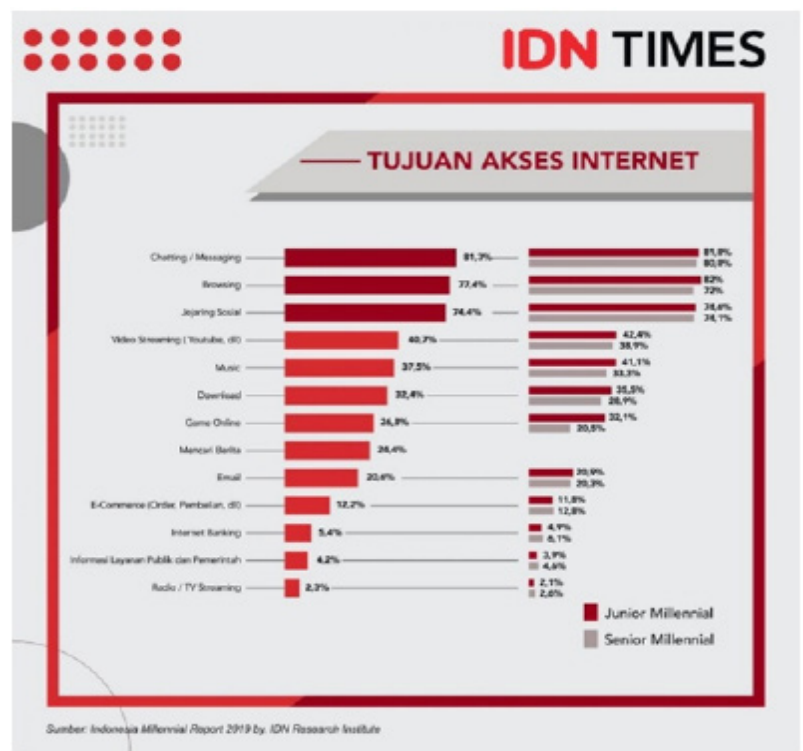

Sumber: idntimes.com, 2019

\section{Gambar 1 Presentase Aktivitas Generasi Millenial Dalam Mengakses Internet}

terkoneksi Internet adalah browsing, jejaring sosial dan video streaming. Sedangkan melalui survei tersebut dinyatakan bahwa tujuan akses Internet untuk melakukan TV streaming mendapatkan presentase terendah yakni 2.3 persen saja.

Inspira TV pun menyadari meski sudah berusaha mengeluarkan aplikasi menonton untuk menyasar target sasarannya, namun kepentingan dalam menonton televisi di layar smartphone bukanlah kegiatan yang sering dilakukan.

Sudah tiga tahun Inspira TV ditetapkan menjadi stasiun televisi digital, berbagaikegiatan branding dalam membangun brand perusahaan pun dilakukan. Tujuannya adalah agar Inspira TV dikenal oleh masyarakat dan dinikmati programnya sehingga dapat menumbuhkan brand yang kuat di tengah persaingan bisnis dengan stasiun televisi lainnya.

Setiap kegiatan yang dilakukan oleh Inspira TV lebih ditujukan untuk generasi millenial karena segmentasi inilah yang menjadi target sasarannya. Padahal segmentasi yang menjadi pasar potensialnya adalah segmentasi dengan usia yang lebih dewasa. Namun untuk mensosialisasikan kepada segmentasi ini dirasa masih banyak kendala yaitu siaran TV digital yang masih sulit untuk diakses dan penggunaan media sosial yang tidak seaktif generasi millenial, sehingga sulit untuk memperkenalkan Inspira TV kepada segmentasi tersebut. Inspira TV pun masih merasakan kendala untuk menguasai pasar Indonesia secara keseluruhan.

Siaran Inspira TV di Indonesia yang masih didominasi TV analog ini masih sulit diakses oleh masyarakat dan segmentasi yang berhasil didapatkan oleh Inspira TV sendiri di dominasi oleh masyarakat dengan golongan menengah atas atau AB. Dengan hal ini Inspira TV tentunya masih sulit menguasai pasar Indonesia karena segmentasi yang didapatkan oleh Inspira TV bukan dari segmentasi yang mendominasi pasar. Dari sebuah penelitian diungkapkan bahwa menurut AGB Nielsen, masyarakat dibagi menjadi 5 segmen yaitu golongan A, golongn $\mathrm{B}$, golongan $\mathrm{C}$, golongan $\mathrm{D}$ dan golongan $\mathrm{E}$ dimana menurut Nielsen mayoritas penduduk Indonesia berada di golongan C (Utami, Dida, 
\& PraStowo, 2017).

Karena adanya ketidaksesuaian antara harapan perusahaan dengan situasi masyarakat Indonesia saat ini membuat kegiatan komunikasi yang dilakukan untuk membangun brand di masyarakat masih belum berjalan secara optimal dan belum mencapai tujuan perusahaan.

Berdasarkan paparan diatas peneliti melihat bahwa Inspira TV kurang memperhatikan faktor-faktor yang dapat mendukung dan menghambat perkembangan perusahaan dalam menentukan target sasarannya. Padahal hal ini sangat penting dilakukan oleh sebuah perusahaan untuk meriset terlebih dahulu kondisi pasarnya atau disebut market research di tahap awal dalam membentuk strategi merek.

Hal tersebut diungkapkan oleh $\mathrm{Xu}$ Yuanzhong dalam penelitiaanya berjudul " $A$ Study On The Relationship Between Public relations and Brand Strategy", bahwa sebagai seorang PR kegiatan market research ini merupakan poin penting dalam tahap awal merencanakan sebuah strategi merek agar strategi yang dilakukan untuk membangun merek perusahaan dapat berjalan dengan efektif karena sudah menyesuaikan dengan kondisi pasar.

Berkaitan dengan kondisi pasar, Inspira TV sudah sepatunya merancang strategi yang berkaitan dengan audiens. Televisi melalui tayangannya akan menyodorkan nilai-nilai tertentu kepada permirsanya (Haryono, 2015). Oleh karena itu dibutuhkan riset mengenai ketersediaan audiens (available audience) yang dapat dihubungkan dengan daypart pada sebuah pemrograman acara (Rubiyanto, 2018). Selain itu, sebagai upaya meraih audiens, juga dapat menggunakan strategi checkerboarding, sebuah strategi untuk meraih jumlah audiens (Kutanto, 2017).

Namun demikian, sebagai stasiun televisi digital, inspira TV, perlu memperhatikan berbagai kebijakan yang ada, misalnya kebijakan desentralisasi di bidang penyiaran (Aminudin, 2016), regulasi penyiaran digital (Sutanto \& Alatas, 2015), serta kode etik jurnalistik dalam memproduksi sebuah program di televisi (Suwadi, 2019), agar upaya branding dapat dilakukan dengan baik, tanpa bersinggungan dengan aspek regulasi.

Maka dari itu, tujuan dari penelitian ini adalah untuk mengetahui fungsi Public relations pada tahap perencanaan, tahap brand positioning, tahap memperkenalkan brand, tahap management brand dan tahap menjaga brand yang dilakukan oleh Inspira TV dalam membangun brand perusahaan.

Fungsi public relations pada strategi merek dari $\mathrm{Xu}$ Yuanzhong ini menjelaskan bahwa di setiap tahapan dalam strategi merek yang efektif memerlukan fungsi Public relations, yang dikemukakan sebagai berikut: 
Pertama, fungsi public relations pada tahap perencanaan strategi merek, dijelaskan bahwa public relations terbagi ke dalam beberapa fungsi yaitu market research, release information dan building inner relations.

Market Research, menurut Xu Yuanzhong, fungsi public relations adalah mengawasi dan menganalisis lingkungan perusahaannya melalui market research, yang terutama diwujudkan adalah bagaimana seorang PR mampu memgumpulkan informasi yang dapat membantu perusahaan untuk lebih memahami kehendak publik. (Yuanzhong, 2005). Riset ini dapat dilakukan dengan menggunakan analisis SWOT. Selanjutnya, dapat ditarik kesimpulan mengenai target pasar dan akhirnya strategi merek dapat terbentuk (Yuanzhong, 2005).

Release information, seorang PR setelah mengumpulkan informasi hasil dari market research adalah bagaimana informasi tersebut dapat disampaikan kepada publiknya melalui berbagai macam media. Tujuan penyampain infromasi ini adalah untuk mendapatkan pemahaman dan dukungan publik, meningkatkan popularitas perusahaan dengan baik dan menciptakan citra sosial dan opini public yang baik.

Building inner relations, PR juga memiliki fungsi untuk membangun hubungan yang baik dengan publik yang berada di dalam perusahaan seperti karyawan. Hubungan internal public relations menekankan beberapa hal yaitu, mencari solidaritas, advokasi manajemen kemanusiaan, berusaha untuk mentransferkan budaya perusahaan, meningkatkan kohesi perusahaan, menumbuhkan rasa kesadaran karyawan dalam memiliki perusahaan.

Kedua, fungsi public relations pada tahap brand positioning yang merupakan tahap dimana perusahaan menentukan perbedaan produk dan jasanya dengan pesaing berdasarkan selera, ide dan perasaan. Brand positioning terdiri dari market positioning dan brand image positioning (Yuanzhong, 2005).

Market positioning, perusahaan harus melakukan market research untuk menentukan positioning yang akan dilakukan di pasarnya dengan cara memperhatikan latar belakang budaya publik, evaluasi publik terhadap produk dan perusahaan dan memahami apakah produk yang ditawarkan sudah sesuai dengan permintaan konsumen.

Brand image positioning menurut Zeng adalah citra yang dipilih oleh pemikiran konsumen dalam menetapkan merek (Yuanzhong, 2005). Fungsi PR disini adalah untuk menetapkan keseluruhan citra perusahaan. Menciptakan citra merek yang positif membutuhkan program pemasaran yang mengaitkan asosiasi merek yang kuat, menguntungkan, dan unik dalam memori (Keller, 2013). Asosiasi merek ini terdiri dari 
atribut merek (brand attributes) dam manfaat merek (brand benefit).

Ketiga, fungsi Public relations pada tahap memperkenalkan merek perusahaan. Beberapa cara yang efektif untuk menarik perhatian konsumen dengan menggunakan fungsi PR menurut Yuanzhong adalah Public relations for remedying the advertisement's shortcoming dan Public relations for social commonweal activities.

Menurut Yuanzhong, public relations dapat memperbaiki kekurangan iklan dan public relations merupakan cara yang paling efektif untuk menyebarluaskan merek (Yuanzhong, 2005).

Public relations for social commonweal activities yaitu untuk mendapatkan citra yang

Tabel 1 Perbedaan Fungsi Advertisement Dengan Pulic Relations

\begin{tabular}{|c|c|}
\hline Advertisements & Public Relations \\
\hline Menyebarkan produk. & $\begin{array}{l}\text { M e } \mathrm{n} \text { y e b a } \mathrm{rk} \text { a } \\
\text { perusahaan. }\end{array}$ \\
\hline $\begin{array}{l}\text { Membuat konsumen } \\
\text { memahami produk dan } \\
\text { layanan perusahaan. }\end{array}$ & $\begin{array}{l}\text { Membangun citra yang } \\
\text { baik. }\end{array}$ \\
\hline $\begin{array}{l}\text { Membuat konsumen } \\
\text { berkeinginan untuk } \\
\text { membeli produk. }\end{array}$ & $\begin{array}{l}\text { Membuat konsumen } \\
\mathrm{m} \text { e } \mathrm{n} \text { e } \mathrm{t} \text { a } \mathrm{h} \mathrm{u} \mathrm{i} \\
\text { perusahaan lebih } \\
\text { baik dan mendukung } \\
\text { perusahaan. }\end{array}$ \\
\hline $\begin{array}{l}\text { Publik membeli produk } \\
\text { secara langsung lalu } \\
\text { mengetahui perusahaan } \\
\text { melalui produknya } \\
\text { tersebut sesuai dengan } \\
\text { pola "the public- } \\
\text { product-enterprise". }\end{array}$ & $\begin{array}{l}\text { Publik mengetahui } \\
\text { perusahaan lalu } \\
\text { membeli produk atau } \\
\text { menggunakan jasa } \\
\text { perusahaan tersebut } \\
\text { sesuai dengan pola } \\
\text { "the public-enterprise- } \\
\text { product". }\end{array}$ \\
\hline
\end{tabular}

Sumber: Hasil diolah peneliti, 2019 baik hal yang dapat dilakukan oleh perusahaan adalah melakukan kegiatan mengenai kepedulian perusahaan dan melakukan kegiatan yang berkontribusi ke masyarakat.

Keempat, fungsi Public Relation pada tahap brand management. Proses brand management bergantung pada cara mendapatkan dan mempertahankan konsumen dan strategi jangka panjang dalam membuat konsumen menjadi brand loyalist (Yuanzhong, 2005). Hal ini dapat dilakukan melalui kegiatan Customer Relation Management (CRM) dan media relations.

CRM dapat dilakukan dengan membuat data base konsumen; mengumpulkan, menganalisis dan menggunakan setiap informasi konsumen (informasi demografi, permintaan, preferensi, pendapatan, dan cara hidup kosumen); menyediakan produk dan layanan khusus; memuaskan kebutuhan khusus konsumen yang berbeda; mengamati atau mengukur respon konsumen; ketika konsumen sangat loyal terhadap merek, mereka tidak ingin berganti ke merek lain; konsumen yang loyal bertindak sebagai role model dan mereka dapat memengaruhi merek secara positif dan dapat menarik konsumen baru (Yuanzhong, 2005).

Dalam proses brand management ini selain membangun hubungan dengan konsumen tetapi perusahaan juga harus membangun hubungan yang baik dengan pihak media.

Selain membina hubungan secara 
fungsional, public relations harus berusaha untuk selalu mengembangkan hubungan interpersonal dengan wartawan (Partao, 2006).

Kelima, fungsi public relations pada tahap menjaga merek. Menurut Zeng (Yuanzhong, 2005), menjaga merek terdiri darilegalprotection dan image protection. Legal protection menurut Zeng, merupakan perlindungan hukum yang dilakukan oleh perusahaan untuk beberapa hal yaitu: mengalahkan produk palsu; mencegah produk di bawah standar; dan menjaga keaslian merek. Sedangkan image protection merupakan cara perusahaan dalam melakukan pengawasan citra dan menangani masalah penting secara tepat waktu (Yuanzhong, 2005)

\section{METODE PENELITIAN}

Penelitian ini menggunakan metode deskriptif dengan jenis data kualitatif. Subjek penelitian dalam penelitian ini adalah pihakpihak yang terlibat dalam pembuatan dan pelaksanaan strategi merek Inspira TV.

Objek dalam penelitian ini adalah fungsi PR pada strategi merek Inspira TV dalam membangun brand perusahaan sebagai stasiun televisi digital yang inspiratif dan positif.

Penelitian ini menggunakan teknik pengumpulan data melalui wawancara mendalam, dokumentasi dan studi pustaka. Wawancara dilakukan kepada beberapa key informant yang ditentukan melalui teknik purposive sampling yaitu teknik penentuan sampel dengan pertimbangan tertentu.

Dari pertimbangan yang sudah ditentukan yaitu pihahk-pihak yang terlibat dalam pembuatan dan pelaksanaan strategi merek Inspira TV, maka didapatkan narasumber dalam penelitian ini adalah; Usman Priatna selaku Head Of Brand Management, Wicky Dwitama selaku Brand Management Manager, Rizky Riansyah selaku Lead Off Air Management, Tri Arnada Sampurizkia selaku Head Of Production and Digital, Lia Amalia selaku Digital Media Development.

Analisis data pada penelitian ini menggunakan analisis data kualitatif menurut Seiddel (Moleong, 2012) prosesnya adalah mencatat hasil lapangan, mengumpulkan, memilah, mengklarifikasi, mensintesiskan, membuat ikhtisar, membuat indeksnya, berpikir dengan jalan membuat agar kategori data mempunyai makna, mencari dan menemukan pola serta membuat temuan-temuan umum.

Teknik validitas data yang digunakan adalah melalui triangulasi sumber, adapun yang menjadi triangulator pada penelitian ini adalah Dodi Irwandi, Fatwa Syarifah dan Lilis Suryani yang merupakan penonton setia Inspira TV dan tergabung dalam grup Whatsapp Sobat Inspira TV.

\section{HASIL DAN PEMBAHASAN}


Tahap pertama yang dilakukan dalam pembuatan strategi merek adalah perencanaan untuk menetapkan prospek jangka panjang dari sebuah perusahaan. Yuanzhong menekankan bahwa dalam tahap ini perusahaan tidak dapat memulai dari imajinasi subjektif tetapi harus memulai dari pendapat konsumen (Yuanzhong, 2005). Pendapat konsumen ini harus dikumpulkan dan dianalisis untuk kemudian menjadi bahan pengambilan keputusan perusahaan dalam melakukan strategi merek.

Pengumpulan informasi ini sangat berkaitan dengan fungsi PR seperti halnya yang diungkapkan oleh Dominick, bahwa Humas memiliki kaitan erat dalam opini publik, pada satu sisi, praktisi humas berupaya untuk memengaruhi publik agar memberikan opini yang positif bagi organisasi atau perusahaan, namun pada sisi lain humas harus berupaya mengumpulkan informasi dari khalayak, menginterpretasikan informasi itu dan melaporkannya kepada manajemen jika informasi itu memiliki pengaruh terhadap keputusan manajemen (Morissan, 2008).

Maka dari itu dalam tahap ini diperlukan market research agar dapat merumuskan strategi merek yang tepat. Dari market research yang dilakukan dapat ditarik kesimpulan mengenai target pasarnya untuk kemudian menjadi acuan bagi perusahaan dalam membuat sebuah strategi merek.
Berdasarkan dari hasil wawancara yang sudah dilakukan, peneliti menemukan ketidaksesuaian antara konsep yang diungkapkan oleh Yuanzhong dengan fenomena yang terjadi dilapangan. Inspira TV tidak melalui tahap market research terlebih dahulu dalam menentukan target pasarnya. Sejak awal berdiri Inspira TV langsung menentukan generasi millenial sebagai target sasarannya, namun pada kenyataannya penonton yang didapatkan oleh Inspira TV bukan target sasaran yang diharapkan. Pada kenyataannya, Inspira TV melakukan market research ini setelah menentukan target untuk mengetahui perkembangan dan feedback yang diberikan kepada perusahaan.

Karakteristikgenerasi millenial di Indonesia sendiri merupakan generasi yang lahir pada tahun 1980-2000, dekat dengan media sosial, kreatif, efisien, mempunyai passion, produktif, dinamis, ingin serba cepat, open minded, kritis dan berani (Budiati, et al., 2018).

Setelah berjalannya perusahaan, pengumpulan informasi mengenai segmentasinya ini tetap dilakukan oleh perusahaan. Berdasarkan hasil wawancara menunjukan bahwa Inspira TV memanfaatkan lembaga survei internal, analisis online dan laporan satelit yang kemudian hasilnya dianalisis menggunakan analisis SWOT (Strength, Weakness, Opportunity, Threat) sebagai bahan 
evaluasi dalam pembuatan program.

Meskipun tidak dilakukan secara teoritis namun analisis SWOT itu secara tidak langsung dibahas setiap membuat perencanaan.

Hasil analisis SWOT tersebut adalah, Inspira TV menganalisis bahwa generasi millenial sebagai generasi yang paling mendominasi masyarakat Indonesia, paling dekat dengan dunia digital dan media online, serta generasi yang karakternya mudah dibentuk dan dipengaruhi dengan sesuatu yang baru. Maka dari itu generasi millenial ini dirasa menjadi peluang bisnis bagi perusahaan.

Hasil studi yang dilakukan oleh Boston Consulting Group (BCG) bersama University of Berkley tahun 2011 di Amerika Serikat tentang generasi millenial USA, mengungkapkan bahwa salah satu karakteristik generasi dimana mereka pasti lebih memilih ponsel daripada televisi. Menonton sebuah acara televisi kini sudah tidak lagi menjadi sebuah hiburan karena apapun bisa mereka temukan di telepon genggam (Budiati, et al., 2018). Hal ini pun disadari oleh Inspira TV dan terbukti mengapa penontonnya bukan generasi millenial melainkan generasi dengan usia yang lebih dewasa.

Kelebihan dan kelemahan Inspira TV pun turut dianalisis dimana kelebihan yang ditawarkan oleh perusahaan adalah konten yang inspiratif dan positif, lalu memiliki SDM di dominasi oleh generasi millenial sehingga konten yang ditawarkan pun dikemas mengikuti tren dan banyak inovasi yang ditawarkan untuk menarik perhatian generasi millenial terhadap perusahaan.

Dari kelebihan yang dimiliki oleh Inspira TV, menjadi TV adalah kelemahan perusahaan. Sebagai TV digital akses masyarakat dalam menonton Inspira TV sangat terbatas karena hingga sekarang pemerintah belum menetapkan regulasi untuk segera migrasi dari analog ke digital sehingga masih banyak masyarakat yang masih belum paham dengan fenomena ini. Selain itu Inspira TV juga sebagai TV digital tidak memiliki riset Nielsen dimana riset inilah yang menjadi nilai jual kepada client saat mencari iklan atau kerja sama. Dari hasil penelitian, perusahaan mengakui bahwa dalam mencari client perusahaan menjadi terhambat karena tidak memiliki hasil rating dan share dari riset Nielsen seperti stasiun televisi analog.

Rating dan share yang dihasilkan oleh AGB Nielsen membuat para stakeholder (TV, Agency, dan Perusahaan Pengiklan) hanya melihat tayangan televisi dari angkaangka tersebut. Rating dan share yang tinggi membuat perusahaan pengiklan dan agencynya akan memasang iklan dalam program tersebut, begitu juga dengan stasiun TV yang dengan suka cita memasangkan program tersebut pada jam sibuk televisi karena uang yang dihasilkan oleh pemasang iklan akan semakin tinggi $(\mathrm{RG}$, 
2018).

Dalam tahap perencanaan ini, langkah selanjutnya yang dilakukan oleh seorang PR dapat menyampaikan informasi perusahaan kepada publiknya melalui berbagai macam media. Dari hasil penelitian yang didapatkan mengenai penyampaian informasi (release information) sudah seusai dengan yang diungkapkan oleh Yuanzhong. Setelah Inspira TV melakukan analisis pasarnya, Inspira TV menggunakan beberapa media online seperti website dan media sosial sebagai sumber informasi untuk mengenalkan perusahaan.

Proses terakhir dari tahap perencanaan adalah bagaimana PR membangun hubungan internalnya, Inspira TV melakukan beberapa kegiatan dan hal ini sudah sesuai dengan hal-hal yang diperhatikan oleh Xu Yuanzhong, sehingga dengan memperkuat hubungan internal antara perusahaan dan karyawan ini bertujuan untuk memobilisasi antusiasme dan kreativitas mereka secara memadai untuk menciptakan lingkungan yang harmonis sehingga dapat mencapai tujuan strategi merek (Yuanzhong, 2005).

Tahap selanjutnya adalah tahap brand positioning yang terdiri dari market positioning dan brand image positioning. Setelah melakukan market research dalam tahap perencanaan, Inspira TV menganalisis bahwa kekuatan perusahaan adalah dari segi konten yang bermuatan inspiratif dan positif dimana
Inspira TV hanya akan menayangkan tayangan yang dapat menginspirasi dan bermanfaat bagi masyarakat. Maka dari itu Inspira TV hadir sebagai media informasi alternatif yang positif, mencerdaskan dan menghibur secara sehat. Hal ini ditetapkan setelah melihat fenomena tayangan TV Indonesia yang kurang mendidik.

Tidak dapat dipungkiri bahwa persaingan industri televisi semakin hari semakin ketat sehingga mendorong para pelaku untuk menghadirkan tayangan yang dapat menarik minat audiens. Semakin tinggi minat audiens terhadap sebuah tayangan maka semakin tinggi juga angka rating dan share dari program tersebut. Tingginya angka rating dan share ini merupakan indikator penting media dalam menarik pengiklan yang menjadi sumber dana terbesar bagi stasiun televisi. Maka dari itu setiap stasiun televisi ini berlomba untuk menaikan angka tersebut tanpa mementingkan kualitas tayangannya karena yang terpenting adalah audiens dapat tertarik dengan tayangan tersebut.

Dalam jurnal Universitas Padjadjaran kajian Televisi dan Film berjudul "Kajian Kritis Tayangan Televisi Favorit Kelas Menengah Perkotaan", terdapat pemantauan Komisi Penyiaran Indonesia (KPI) terhadap 1.100 tayangan televisi pada tahun 2014, menemukan hanya $27 \%$ yang aman dari kekerasan, seks dan mistik sedangkan $73 \%$ lainnya dinilai 
mengandung salah satu dari ketiga unsur tersebut (Gemiharto, Abdullah, \& Puspitasari, 2017). Masih dari hasil survei KPI, didapati jenis program infotainment, sinetron, dan variety show yang kerap merajai jam tayang televisi nasional mendapat rapor merah KPI dengan perolehan skor di kisaran 2,3-2,5. Konten ketiga jenis program tersebut dinilai masih belum berkualitas dan kurang mendidik (Winata, 2018)

Disaat stasiun televisi bersaing untuk menyajikan tayangan yang kurang mendidik, Inspira TV hadir berbeda dengan tayangan yang lebih berkualitas. Sesuai dengan visi misi perusahaan, Inspira TV ingin menjadi stasiun televisi digital dengan semangat "Inspiratif Dan Positif'. Dari hal tersebut Inspira TV berhasil membuat perbedaan yang sangat jelas antara programnya dengan program di stasiun televisi lain.

Onong Uchjana Effendy dalam bukunya "Hubungan Masyarakat" mengemukakan empat fungsi Public relations yang dua diantaranya adalah 1) menciptakan komunikasi dua arah timbal balik dengan menyebarkan informasi dari organisasi kepada publik dan menyalurkan opini publik kepada organisasi, 2) melayani publik serta menasihati pimpinan organisasi demi kepentingan umum (Yulianita, 2007). Dalam hal ini maka public relations harus peka terhadap publiknya, apa yang diinginkan oleh publik dan bagaimana respon yang diberikan publik terhadap perusahaan sehingga dapat ditindaklanjuti melalui kebijakan perusahaan yang disesuaikan dengan kebutuhan publiknya tersebut.

Dari hasil penelitian, Inspira TV mendapatkan respon dari audiensnya yaitu melalui hotline service perusahaan yag dicantumkan dalam running text programnya. Sehingga dalam hal ini terjadi komunikasi dua arah dimana audiens bisa memberikan feedback secara langsung kepada perusahaam ketika sedang menonton program Inspira TV. Dengan hal ini Inspira TV dapat melihat siapa penontonya, bagaimana latar belakangnya, seperti apa keinginannya dan apa yang dibutuhkan oleh penontonnya untuk kemudian dijadikan sebagai bahan pengambilan keputusan, dapat dilihat pada gambar 2 .

Melalui respon yang diberikan oleh penonton Inspira TV dapat diketahui bahwa tayangannya ini lebih banyak dinikmati oleh segmentasi pasar dengan usia dewasa dengan status ekonomi menengah ke atas. Hal ini diakui oleh perusahaan bahwa terjadi perbedaan antara apa yang diharapkan dengan apa yang perusahaan dapatkan. Jika sejak awal Inspira TV menargetkan tayangannya dapat dinikmati oleh generasi millenial, tetapi kenyataannya programnya ini lebih sesuai untuk segmentasi usia yang lebih dewasa dengan penghasilan 


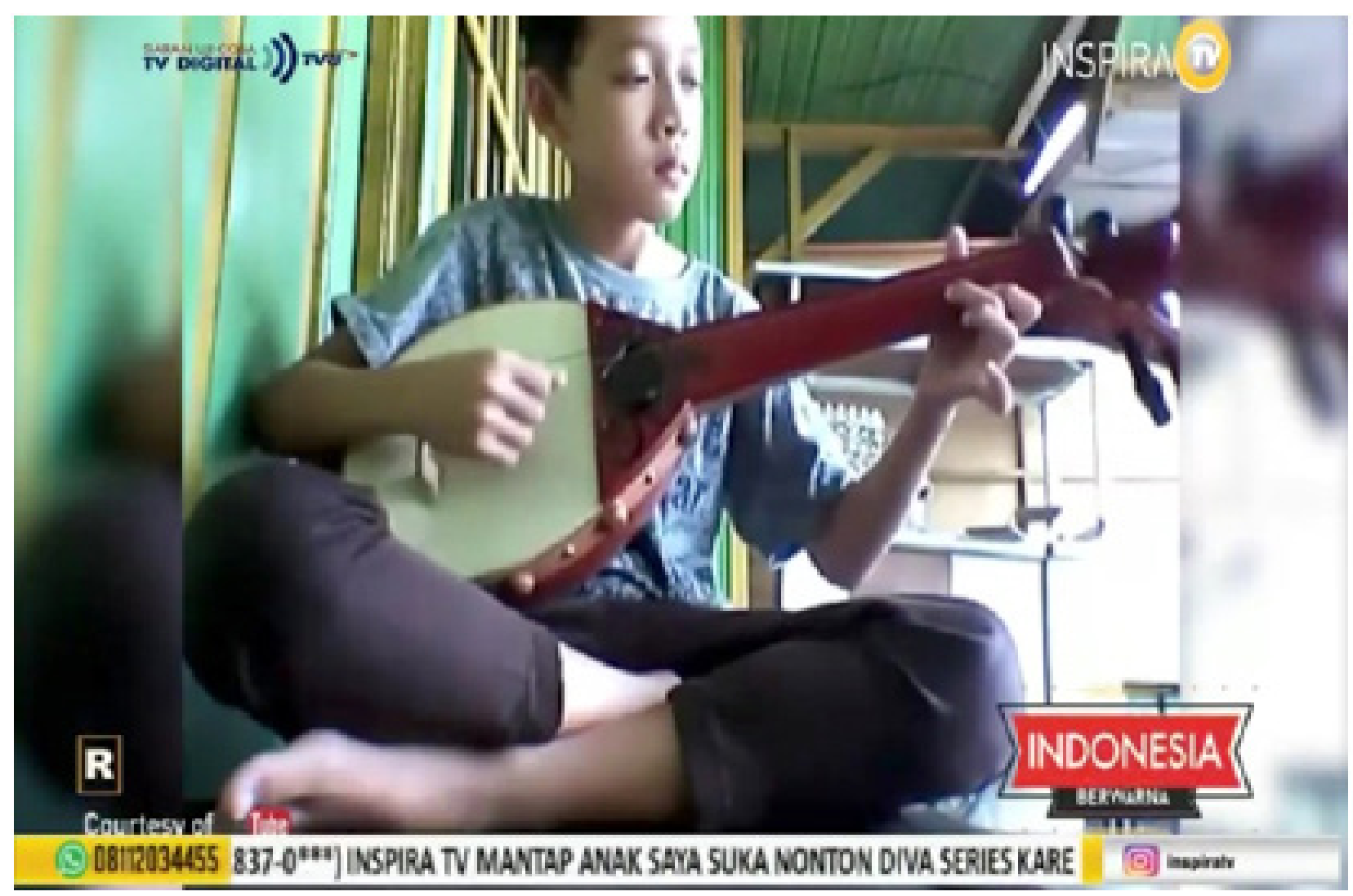

Sumber: Aplikasi Inspira TV, 2019

Gambar 2 Pencantuman Nomor Hotline Service Inspira TV Pada Bagian Running Text Dalam Program On Air Inspira TV.

yang berpotensi untuk menyaksikan tayangan TV digital melalui perangkat tambahan.

Yuanzhong mengungkapkan bahwa "brand is born particullary for some specific consumer group segmentation market". Dimana melalui pernyataan ini diartikan bahwa hadirnya sebuah merek diperuntukan bagi segmentasi pasar konsumen tertentu saja. Maka dari itu bagaimana cara mendapatkan segmentasi ini menjadi titik penting dalam membangun merek perusahaan secara efektif melalui brand positioning (Yuanzhong, 2005). Tetapi hal ini tidak sesuai dengan apa yang dilakukan oleh Inspira TV karena target sasarannya adalah generasi millenial sehingga dalam pelaksanaan strategi mereknya lebih menyasar kepada generasi tersebut sehingga untuk mendapatkan potensial pasarnya menjadi kurang efektif. Selain itu hal ini tidak sesuai dengan kenyataannya dimana Inspira TV ingin merangkul semua kalangan di Indonesia sedangkan tayangan Inspira TV hanya dapat dinikmati oleh segmentasi tertentu saja.

Fungsi PR yang kedua adalah untuk menetapkan keseluruhan citra. Menurut Zeng $\mathrm{Lu}$, brand image positioning adalah citra 
yang dipilih oleh pemikiran konsumen dalam menetapkan merek. Seperti yang diungkapkan di hasil penelitian dalam hal ini Inspira TV ingin menjadi stasiun televisi digital yang inspiratif dan positif (Yuanzhong, 2005).

Penentuan strategi merek salah satu dari lima pilihan adalah terdapat beberapa merek tambahan yang ingin diperkenalkan atau disebut multi brand (Rangkuti, 2009). Multi brand dapat terjadi apabila perusahaan memperkenalkan berbagai merek tambahan dalam kategori produk yang sama. Ada berbagai alasan untuk melakukan hal ini. Tujuannya adalah untuk mencoba membentuk kesan, kenampakan (feature) serta daya tarik lain kepada konsumen sehingga lebih banyak pilihan.

Hal ini sesuai dengan cara yang dilakukan oleh Inspira TV dalam menentukan akan seperti apa mereknya dipandang oleh audiens yaitu dengan menambahkan merek lain mengenai perusahaan secara utuh. Inspira TV tidak hanya ingin dikenal sebagai media inspiratif dan positif tetapi juga dalam mengenalkan perusahaannya, Inspira TV membentuk kesan lain melalui tagline "Televisi Digital Indonesia" untuk menjadi feature lain selain tagline "Inspiratif \&Positif". Sehingga dengan hal ini Inspira TV ingin menanmkan kepada masyarakat bahwa terdapat stasiun televisi digital Indonesia yaitu Inspira TV sebagai stasiun televisi yang memberikan tayangan Inspiratif dan Positif bila dibandingkan dengan stasiun televisi lainnya.

Menciptakan citra merek yang positif membutuhkan program pemasaran yang mengaitkan asosiasi merek yang kuat, menguntungkan, dan unik dalam memori (Keller, 2013). Asosiasi merek dapat berupa atribut merek dan manfaat merek.Atribut merek (brand attributes) adalah fitur deskriptif yang menjadi ciri produk atau layanan.

Dalam menyampaikan brand imagenya sebagai televisi digital yang inspiratif dan positif, Inspira TV menggunakan beberapa fitur yang menjadi ciri khas perusahaan. Hal ini terdiri dari tagline "Inspiratif \& Positif", tagline "Televisi Digital Indonesia", logo, warna hitam dan kuning serta gaya taltent yang digunakan dalam siarannya. Masing-masing fitur ini memiliki makna tersendiri untuk menyampaikan brand image tersebut.

Hal yang kedua dalam membentuk asosiasi merek adalah manfaat merek (brand benefits) adalah nilai pribadi dan makna yang terbentuk oleh konsumen dengan atribut produk atau layanan.Untuk manfaat merek itu sendiri, Inspira TV menyampaikannya melalui programnya. Sesuai dengan hasil penelitian bahwa dalam membentuk citra perusahaan yang Inspiratif dan Positif tersebut dapat dirasakan langsung oleh auidens ketika menikmati programnya.

Setelah melakukan brand positioning, perusahaan harus menyebarluaskan mereknya 
yang juga memerlukan dukungan dari Public relations. Hasil penelitian menunjukan bahwa dalam melakukan tahap memperkenalkan merek perusahaan, Inspira TV berfokus pada tiga strategi yaitu strategi on air, off air dan online.

Inspira TV menyusun berbagai upaya untuk mencapai hasil akhirnya adalah membuat masyarakat mengenal Inspira TV. Tujuan Inspira TV sendiri adalah bagaimana masyarakat mengetahui keberadaan Inspira TV sebagai stasiun televisi digital yang inspiratif dan positif. Sehingga ketika Indonesia sudah bermigrasi ke sistem penyiaran TV digital, Inspira TV sudah dikenal dan mendapatkkan keuntungan perusahaan.

Hasil penelitian menunjukan bahwa strategi on air yang digunakan oleh Inspira TV dalam memperkenalkan programnya yaitu dengan menggunakan iklan di siaran on airnya. Inspira TV juga membuat iklan yang dapat mengedukasi audiensnya mengenai TV digital untuk menambah pemahaman terhadap fenomena televisi digital saat ini. Untuk lebih menarik audiensnya dan menumbuhkan citra positif terhadap perusahaan, Inspira TV membangun komunikasi dua arah dengan audiensnya melalui program interaktif. Program interaktif ini dilakukan melalui kuis berhadiah yang dilakukan saat siaran langsung ataupun melalui program yang kemudian diarahkan ke media sosial Inspira TV. Hal ini pun cukup berdampak dalam menarik publiknya menyaksikan Inspira TV seperti diungkapkan oleh Fatwa Syarifah, salah satu triangulator yang tertarik dengan tayangan Inspira TV karena terdapat hadiahhadiah menarik yang ditawarkan, dapat dilihat pada gambar 3 .

Dari hasil penelitian, media yang sering digunakan untuk beriklan oleh Inspira TV adalah media luar ruang dan media promo di media elektronik ataupun media cetak. Menurut Usman Priatna, melalui iklan ini Inspira TV hanya ingin memperkenalkan perusahaan dan untuk menarik publiknya menonton siaran televisinya perlu dikembangkan lagi melalui beberapa cara. Maka dari itu untuk mengenalkan perusahaan ke masyarakat yang lebih luas terutama generasi millenial, Inspira TV menggunakan strategi online yakni melalui website dan media sosial. Instagram dan Facebook digunakan untuk mempromosikan program on air dan kegiatan off air Inspira TV. Pengikut akun Instagram Inspira TV sendiri didominasi oleh anak muda sehingga untuk menarik perhatian followersnya, konten yang disajikan melalui Instagram tidak hanya mengenai programnya saja tetapi juga mengenai informasi-informasi perusahaan yang dikemas mengikuti sesuatu yang sedang hangat diperbincangkan di mesia sosial. Selain itu optimalisasi akun Youtube juga dilakukan dalam strategi online ini dimana tayangan yang 

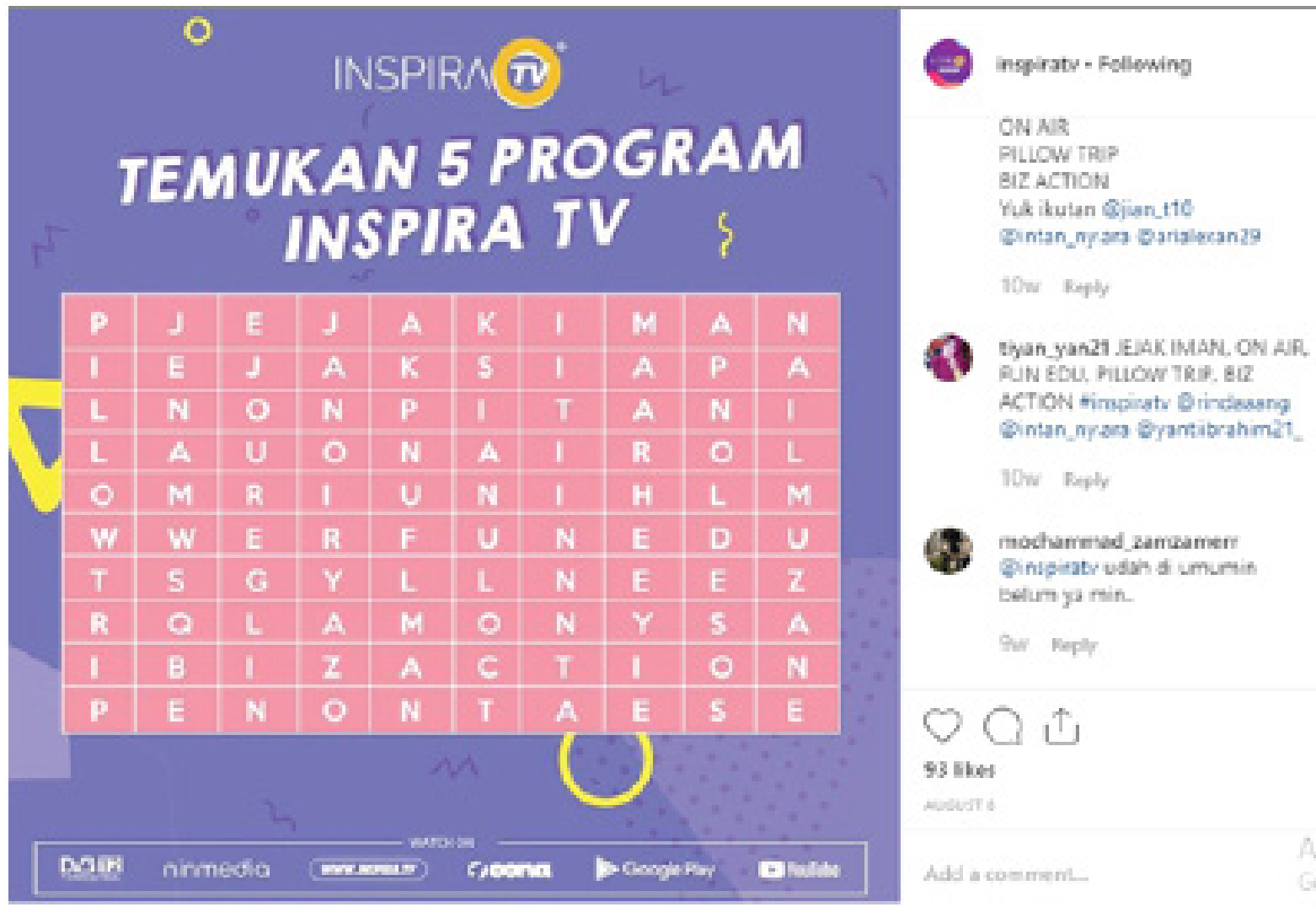

Sumber: Instagram, 2019

Gambar 3 Kuis Media Sosial Yang Diunggah Oleh Inspira TV

disajikan disesuaikan dengan karakteristik generasi millenial. Melalui konten-kontennya inilah Inspira TV dapat membuat pengikutnya lebih mengetahui perusahaan dengan informasi yang dikemas semenarik mungkin sehingga perusahaan mendapatkan dukungan dari pengikutnya di media sosial. Kuis berhadiah pun dilakukan melalui strategi online ini untuk lebih meningkatkan engagement dengan para pengikutnya.

Jika dilihat dari hal tersebut dapat dihubungkan dengan strategi off air Inspira TV dengan membuat sebuah event dimana publik yang datang ke event Inspira TV akan mengetahui perusahaan terlebih dahulu sebelum mereka mengenal programnya. Melalui strategi off air ini perusahaan berkesempatan untuk berkomunikasi face to face dengan publiknya dimana ada keterlibatan secara langsung antara perusahaan dengan publik. Sehingga dalam pengenalannya pun akan semakin efektif bila dibandingkan dengan penggunaan media massa dengan cakupan publik yang lebih luas. Maka dari itu untuk memaksimalkan strategi off airnya, Inspira TV langsung mengajak para pengunjung untuk memfollow akun media sosial dan juga mendownload aplikasi Inspira TV. Dengan begitu setelah publik mengetahui 
perusahaan barulah mereka mengetahui program-programnya seperti apa.

Dari penjabaran tersebut terlihat bahwa Inspira TV banyak melibatkan public relations dalam memperkernalkan perusahaan dapat menyempurnakan iklan. Sama halnya dengan Inspira TV yang merasa kurang efektif dalam penggunaan iklan apabila untuk menarik publik menonton siarannya. Maka dari itu diperlukan dukungan PR dalam menciptakan komunikasi dua arah dengan membangun interaksi dan melibatkan publiknya secara langsung untuk menarik perhatian publiknya. Seperti yang diungkapkan oleh Yuanzhong, perusahaan harus menggunakan cara yang efektif untuk menarik perhatian konsumen selain dari iklan karena Public relations lebih komprehensif dibandingkan iklan (Yuanzhong, 2005).

Untuk mengenalkan perusahaan dan mendapatkan citra yang baik dari publiknya, perusahaan juga dapat melakukan kegiatan sosial.Inspira TV cukup aktif berpartisipasi dalam kegiatan sosial melalui kerja sama dengan lembaga-lembaga sosial sebagai media partner. Dalam hal ini Inspira TV membantu untuk menginformasikan dan mempublikasikan kegiatan tersebut kepada khalayak. Sehingga dalam hal ini Inspira TV ikut peduli dengan lingkungan sosialnya. Inspira TV juga sering menurunkan relawan untuk turut berkontribusi langsung kepada masyarakat. Dengan hal ini Inspira TV sudah sesuai dengan apa yang dinyatakan oleh Yuanzhong.

Untuk membangun hubungan baik antara merek dengan konsumen adalah melalui customer relation management (CRM). Berhubungan dengan hal tersebut, Inspira TV membuat wadah untuk membangun hubungan yang lebih dekat dengan publiknya melalui grup Sobat Inspira dan grup kegiatan off air. Dengan sebutan Sobat Inspira kepada penontonnya ini pun menjadi salah satu cara Inspira TV memberikan value terhadap hubungan antara penonton dengan perusahaan. Untuk mempertahankan penonton yang sudah berada dalam grup ini, Inspira TV selalu membangun interaksi dalam grup tersebut dan cepat tanggap dalam merespon pesan Sobat Inspira. Dan hal ini pun dirasakan oleh Fatwa Syarifah dan Dodi Irwandi sebagai triangulator.

Dalam melakukan Customer Relation Management, hal-hal yang diperhatikan adalah CRM dilakukan dengan membuat data base konsumen. Sesuai dengan hasil penelitian, data base penontonya ini didapatkan dari pesan Whatsapp yang masuk serta dari hasil analisis online yakni Instgram dan Google Analytic.

Dari data base yang sudah ada tersebut informasi yang diperoleh Inspira TV tidak sebanyak seperti yang diungkapkan oleh Yuanzhong. Melalui hasil analisis online tersebut Inspira TV hanya dapat mengetahui 
informasi demografi, usia dari publiknya serta permintaan publiknya. Inspira TV juga memberikan merchandise ataupun hadiah secara bergantian kepada setiap anggota yang tergabung dalam Sobat Inspira sebagai bentuk apresiasi perusahaan kepada penontonnya.

Salah satu faktor yang harus diperhatikan dalam tahap ini adalah memuaskan kebutuhan khusus konsumen yang berbeda. Dalam hal ini dapat dihubungkan dengan cara Inspira TV memprioritaskan anggota grup Sobat Inspira ketika mengikuti kuis. Hasilnya pun diakui oleh ketiga triangulator yang menyataakan mereka pernah sebanyak dua kali mendapatkan merchandise dan hadiah dari Inspira TV baik sebagai pemirsa pilihan ataupun setelah mengikuti kuis.

Menurut Yuanzhong, ketika konsumen sangat loyal terhadap merek, mereka tidak ingin berganti ke merek lain. Dan hal ini pun sesuai denga hasil wawancara dengan salah satu Sobat Inspira sebagai triangulator dalam penelitian yang mengungkapkan bahwa dirinya tidak menonton TV digital selain Inspira TV.

Konsumen yang loyal bertindak sebagai role model dan mereka dapat memengaruhi merek secara positif dan dapat menarik konsumen baru. Dodi Irwandi sebagai salah satu penonton setianya ini melakukan hal tersebut, dimana dirinya secara tidak langsung turut memperkenalkan Inspira TV dan berharap pasarnya akan meluas.

Berdasarkan hasil penelitian, Inspira TV juga menjalin hubungan dengan sesama rekan media melalui kerja sama yang saling menguntungkan dengan media cetak, radio maupun online. Namun, kerja sama yang dilakukan ini lebih banyak dilakukan untuk mempromosikan program Inspira TV dan sebaliknya media lain pun ikut mempromosikan di Inspira TV. Tetapi jika Inspira TV melakukan kegiatan off air, pihak media lain turut diundang untuk meliput kegiatannya. Dan sejauh ini Inspira TV sendiri tidak pernah mendapatkan pemberitaan yang buruk dari media lain.

Zainal Abidin Partao berpendapat bahwa salah satu cara membangun hubungan dengan media adalah melakukan pendekatan yang sistematis dan bijaksana. Bahwa selain membina hubungan secara fungsional, Public relations harus berusaha untuk selalu mengembangkan hubungan interpersonal dengan wartawan (Partao, 2006).

Bila dilihat dari penjabaran di atas, hubungan kerja sama yang sudah dijelaskan sebelumnya merupakan hubungan fungsional dimana antara Inspira TV dengan rekan media lainnya saling melakukan pendekatan sebagai orang yang bekerja pada institusi media massa. Selain itu pun sesuai dengan hasil wawancara Inspira TV juga membangun hubungan interpersonal satu sama lain diluar kepentingan 
pekerjaan.

Fungsi komunikasi public relations dijalankan melalui strategi merek perusahaan setiap saat. Ketika perusahaan menjalankan strategi merek, terlepas dari susunan objek merek, mereka membutuhkan komunikasi public relations dalam melakukan brand positioning atau menjaga merek dan sebagainya (Yuanzhong, 2005).

Dalam menjaga mereknya, sebuah perusahaan tentunya harus melakukan perlindungan hukum atau legal protection. Secara hukum Inspira TV sendiri sudah mendaftarkan logo serta nama resminya sebagai PT. Inspira Televisi Indonesia di daftar stasiun televisi yang mengikuti masa uji coba dengan izin penyiaran di 6 wilayah di Indonesia.

Selain itu, untuk mencegah produknya di bawah standar, meskipun tidak secara hukum tetapi Inspira TV memiliki Standar Operasional Prosedur (SOP) yang harus dipenuhi dalam pembuatan programnya. Untuk menjaga keaslian merek. Inspira TV juga membuat brand guideline agar tidak ada perubahan yang dilakukan terhadap logo.

Zeng mengemukakan bahwa image protection atau perlindungan citra merupakan cara perusahaan dalam melakukan pengawasan citra dan menangani masalah penting secara tepat waktu (Yuanzhong, 2005).

Dari hasil penelitian, dapat dihubungkan bahwa dalam menjaga citranya, Inspira TV selalu berhati-hati membuat sebuah konten. Terutama konten di media sosial pun sangat diperhatikan karena sangat rentan terhadap isu-isu. Selain itu Inspira TV juga selalu cepat tanggap dalam menangani isu-isu terkait perusahaan. Hal tersebut dilakukan dengan mensosialisasikan kembali informasi terkait permasahan dan mengedukasi agar menciptakan pemahaman publik terhadap perusahaan.

Sejauh ini Inspira TV sendiri tidak pernah mengalami krisis yang berdampak tinggi pada kelangsungan perusahaan. Seperti dari hasil penelitian diungkapkan bahwa Inspira TV pernah mendapatkan asumsi-asumsi yang kurang baik mengenai perusahaan.

Seperti diungkapkan dalam sebuah penelitian bahwa dalam menjaga merek terdapat manajemen isu dan manajemen krisis dimana isu merupakan kondisi atau peristiwa yang akan terus berlanjut jika tidak ditangani dan akan berpengaruh secara signifikan pada kinerja perusahaan sehingga dapat berdampak menjadi sebuah krisis perusahaan (Jaques, 2017). Dan hal ini dilakukan oleh Inspira TV dengan cepat untuk menangani isu-isu mengenai perusahaan agar tidak berkembang menjadi krisis.

\section{SIMPULAN}

Berdasarkan seluruh hasil penelitian dan pembahasan mengenai fungsi public relations 
pada strategi merek Inspira TV, peneliti menarik kesimpulan sebagai berikut:

Fungsi public relations pada tahap perencanaan strategi merek yang dilakukan oleh Inspira TV adalah menentukan menentukan target sasaran, melakukan proses market research, melakukan analisis SWOT, menentukan pemilihan media untuk menyampaikan informasi dan produk perusahaan, menjalin hubungan internal melalui berbagai kegiatan utnuk meningkatkan motivasi karyawan sehingga dapat mewujudkan tujuan perusahaan melalui strategi merek. Dalam tahap ini terdapat hal yang tidak sesuai dengan konsep fungsi Public relations dalam strategi merek milik $\mathrm{Xu}$ Yuanzhong dimana target sasaran seharusnya ditetapkan setelah melalui proses market research.

Fungsi public relations dalam tahap brand positioning adalah Inspira TV menawarkan program siaran yang dapat menginspirasi dan juga bermanfaat bagi penontonnya melalui konten siaran yang positif sebagai pembeda dengan TV lain. Perbedaan ini disampaikan melalui proses market positioning dimana dengan kualitas konten yang ditawarkan oleh perusahaan, segmentasi yang didapatkan oleh Inspira TV tidak sesuai dengan segmentasi yang sudah ditentukan sebelumnya. Inspira TV sendiri ingin menanamkan brand image di benak masyarakat sebagai Stasiun Televisi
Digital yang Inspiratif dan Positif dan disampaikan dengan menggunakan beberapa ciri khas perusahaan seperti tagline "Inspiratif \& Positif”, tagline “Televisi Digital Indonesia", logo, penggunaan warna hitam dan kuning serta talent yang digunakan.

Dalam tahap memperkenalkan brand perusahaan, Inspira TV melakukan tiga strategi yaitu strategi On Air, Off Air dan Online yang saling terintegrasi satu sama lain. Melalui tiga strategi ini Inspira TV mempromosikan produk perusahaan melalui iklan dan untuk menciptakan citra positif perusahaan, Inspira TV selalu membangun interaksi dengan audiensnya, membuat kuis berhadiah dan aktif melakukan kegiatan sosial.

Melalui tahap brand management fungsi Public relations yang dilakukan oleh Inspira TV memberi sebutan Sobat Inspira bagi audiensnya untuk memunculkan keterikatan antara perusahaan dan audiens. Kegiatan Customer Relation Management (CRM) dilakukan oleh Inspira TV dalam mempertahankan audiensnya yaitu dengan membuat grup Whatsapp berisikan penonton setia, membangun komunikasi dengan anggota yang tergabung dalam grup tersebut, mengapresiasi penontonnnya dengan memberikan merchandise dan hadiah. Inspira TV juga selalu menjaga hubungan baik dengan sesama rekan media lainnya melalui proses media relations baik menjaga hubungan 
fungsional maupun hubungan interpersonal.

Fungsi public relations dalam tahap brand protection yang dilakukan oleh Inspira TV dalam proses legal protection yaitu mendaftarkan nama perusahaan secara resmi dengan nama PT. Inspira Televisi Indonesia, menjaga kualitas program dengan membuat Standar Operasional Prosedur (SOP) dan membuat brand guideline. Untuk menjaga citra perusahaan mengenai isu-isu yang kurang baik, Inspira TV selalu mensosialisasi dan mengedukasi kembali kepada masyarakat, memperhatikan konten media sosial, merespon secara aktif dan memberikan solusi jika ada pengaduan dan selalu siap mempertanggung jawabkan program yang ditayangkan.

Berdasarkan seluruh simpulan tersebut, peneliti memberi saran sebagai berikut:

Dalam melaksanakan market research, Inspira TV juga dapat mengumpulkan data mengenai pasar potensialnya melalui lembaga riset internal yang dimiliki perusahaan sehingga strategi komunikasi yang dilaksanakan oleh Inspira TV dapat lebih tepat sasaran.

Inspira TV dapat melakukan strategi off air yang lebih menyasar untuk pasar potensialnya. Hal ini dapat dilakukan melalui kerjasama dengan instansi atau perusahaan lain yang memiliki segmentasi dewasa sehingga jangakuan pasarnya bisa lebih luas.

Dalam melaksanakan brand management
Inspira TV dapat melakukan survei yang lebih mendalam mengenai karakteristik segmentasi yang didapatkannya, hal ini dapat dilakukan melalui pembagian kuisioner berupa link di grup Whatsapp Sobat Inspira. Sehingga Inspira TV dapat memberikan layanan yang sesuai dengan masing-masing karakteristik penontonnya.

Penonton setia Inspira TV tersebar ke berbagai daerah di Indonesia, hal ini dapat menjadi referensi bagi perusahaan untuk membuat event roadshow dengan mengunjungi beberapa daerah yang memiliki potensial pasarnya.

Perlu dilakukan penelitian lanjutan mengenai fungsi PR pada strategi merek dalam membangun brand perusahaan dengan ruang lingkup penelitian yang lebih luas.

\section{DAFTAR PUSTAKA}

Abdullah, A., \& Puspitasari, L. (2018). Media televisi di era Internet. ProTVF: Jurnal Kajian Televisi dan Film, 101-110.

Abimbola, T. (2010). Brand strategy as a paradigm for marketing competitiveness. Journal Of Brand Management, 177-179.

Aminudin, A. (2016). Implementasi regulasi sistem stasiun jaringan (Analisis Ekonomi Politik Media Pada RCTI Network Banten). Journal Communication, 7(1), 47-62. https://doi.org/10.5151/cidi2017-060

Budiati, I., Susianto, Y., Ponco, W., Ayuni, S., Reagan, H. A., Larasaty, P., Saputri, V. G. (2018). Buku profil generasi 
milenial Indonesia. Jakarta: Kementerian Pemberdayaan Perempuan dan Perlindungan Anak.

Gemiharto, I., Abdullah, A., \& Puspitasari, L. (2017). Kajian kritis tayangan televisi favorit kelas menengah perkotaan. Jurnal Kajian Televisi Dan Film, 1(1) 13-29.

Haryono, C. G. (2015). Program Sahur ditelevisi:

Konspirasi “Indah Nan Mempesona" antara kapitalisme dan industri budaya populer. Jurnal Bricolage, 1(1), 114-127.

Jaques, T. (2017). Issue management and crisis management:an integrated, non-linear, relational construct. Public relations Review, 147-157.

Keller, K. L. (2013). Strategic brand management, building, measuring, and managing brand equity. New Jersey: Person Education.

Kutanto, H. (2017). Strategi programming dalam pengemasan program "Hafiz Indonesia 2015" RCTI untuk memperoleh rating share tinggi. Communication, VIII(2), 41-63.

Moleong, L. J. (2012). Metode penelitian kualitatif. Bandung: Remaja Rosdakarya.

Morissan. (2008). Manajemen public relations: strategi menjadi humas profesional. Jakarta: Kencana Prenada Media Group.

Partao, Z. A. (2006). Media relations, strategi meraih dukungan publik. Jakarta: Indeks.

Rangkuti, F. (2009). The power of brands. Jakarta: Gramedia Pustaka Utama'.
RG. (2018, Agustus 24). Komisi penyiaran Indonesia. Dipetik Januari 13, 2020, dari http://www.kpi.go.id/

Rubiyanto. (2018). Strategi membidik ketersediaan audiens dalam industri televisi (Studi Deskriptif Tayangan Film India ANTV). Bricolage: Jurnal Magister Ilmu Komunikasi, 4(1), 83-94. https://doi. org/10.30813/bricolage.v4i01.1069

Sukmadinata, N. S. (2009). Metode penelitian pendidikan. Bandung: Remaja Rosdakarya.

Sutanto, V. W., \& Alatas, S. (2015). Menyoal regulasi penyiaran digital (Studi terhadap Kepentingan Publik dalam Regulasi Televisi Digital di Indonesia). Avant Garde, 3(2), 237-249.

Suwadi. (2019). Kode Etik Jurnalistik Dan Independensi Produksi Program Televisi Investigasi. Avant Garde, 7(1), 80. https:// doi.org/10.36080/avg.v7i1.852

Utami, S. P., Dida, S., \& Prastowo, F. A. (2017). Strategi perencanaan public relations net. tv dalam membentuk citranya sebagai televisi masa kini. ProTVF: Jurnal Kajian Televisi dan Film, 1(1) 61-76.

Winata, D. K. (2018, Juli 25). Media Indonesia. Diambil kembali dari https:// mediaindonesia.com

Yuanzhong, X. (2005). A study on the relationship between public relations and brand strategy. DiVa Portal.

Yulianita, N. (2007). Dasar-dasar public relations. Bandung: P2U - LPPM UNISBA. 